\title{
Is Tongue-Tie a Fad?
}

\section{Patricia Berg-Drazin}

$R L C, I B C L C, C S T-D$

\section{Introduction}

Awareness of ankyloglossia commonly known as tongue-tie is increasing. We are learning that not releasing the tongue can have lifelong consequences on one's health and well-being. These can range from the simple pleasures of a full range of foods to affecting ones' sleep and cognitive abilities.

International Board-Certified Lactation Consultants are discussing with families the lack of range of motion they see in the tongue and resultant tension in the baby's oral anatomy. Families visiting their medical practitioners questioning if it is possible that their baby has a tongue-tie are often told that ankyloglossia or tongue-tie is just a fad.

Research should form the basis used in decision making. The following is a sampling of the historical references on ankyloglossia.

"The history of the word tongue-tie" is very old. It goes back to the Old Testament which was believed to be written between 1200- 165 BC. The oldest extant Japanese Medical book - Ishinhou- describes frenotomy when ankyloglossia was observed in an infant. In Europe we can date back to Aristotle (384-32BC) [1].

Following is a sampling

Old Testament Exodus 4:10:

Moses said to the LORD, "O my Lord, I am not eloquent, neither heretofore, nor since thou has spoken unto thy servant: but I am slow of speech, and of a slow tongue" [2].

While not definitive, slow of speech and tongue are common with tongue tie!

King James Version Bible- Mark 7: 35:

"And the string of his tongue was loosed, and he spake plain" [3].

Aristotle in the $3^{\text {rd }}$ century BC:

"This same softness again, together with its breadth, adapts it for the articulation of letters and for speech. For these qualities, combined with its freedom from attachment, are those which suit it best for advancing and retiring in every direction. That this is so is plain, if we consider the case of those who are tongue-tied in however slight a degree. For their speech is indistinct and lisping; that is to say there are certain letters which they cannot pronounce" [4].

Aulus Cornelius Celsus (encyclopaedist known for his extant medical work) in the first century AD:

"In some the tongue is really attached to its base from the first day of life onwards, who therefore cannot speak. In them, the tongue's tip should be seized with a small forceps and the membrane thereunder incised, with great care not to violate the veins which are close and may harm by profuse bleeding... Who is thereby healed, mostly can speak. But I have seen one who after cutting could protrude the tongue beyond the teeth, but still did not gain the ability to speak. In medicine it may

\section{Publication History:}

Received: October 03, 2020

Accepted: December 28, 2020

Published: December 30, 2020

\section{Keywords:}

Ankyloglossia, Tongue-tie, Lactation, Breastfeeding, Craniosacral therapy

be universally valid what should be done, but not universally valid what results and whom it helps" [5].

Galen of Pergamon (physician, surgeon) second century AD:

"Again the tongue in some persons is tied down from birth to the part underlying it, and on this account they cannot even speak. In such cases the extremity of the tongue is to be seized with a forceps, and the membrane under it incised, great care being taken lest the blood vessels close by are injured and bleeding causes harm. The treatment of the wound afterwards has been described above. And indeed many when the wound has healed have spoken; I have, however, known a case when, though the tongue has been undercut so that it could be protruded well beyond the teeth, nevertheless the power of speech has not followed. So it is that in the Art of Medicine even where there is a rule as to what ought to be done, yet there is no rule as to what result ensues" [6].

John Pechey - 1697:

"She must put her finger into the Mouth and cleanse it from filth, and see whether the Child be Tongue-tied or not" [7].

An Eminent Physician - 1729:

"Very often the Membrane under the Tongue is so short and strait, that it hinders the Child from sucking, and puts him in a Condition of never being able to speak distinctly all his Life; but these Inconveniencies are easily removed by a slight incision. It likewise happens very often, that the inside of young Children's Mouths is sore and ulcerated, which Sorenefs is increased by their rubbing their Gums together, and if not carefully removed not only hinders them from sucking but makes them die in Torment" [8].

John Theobald -1764:

"The tongue is sometimes so closely tied to the lower part of the mouth, by the means of the brindle, that it is obligated to be cut; this is usually done by nurses and midwives with their nail" [9].

"Corresponding Author: Patricia Berg-Drazin, RLC, IBCLC, CST-D ; E-mail: patricia@pbdrazin.com

Citation: Berg-Drazin P (2020) Is Tongue-Tie a Fad?. Int J Pediatr Neonat Care 6 : 169. doi: https://doi.org/10.15344/2455-2364/2020/170

Copyright: (c) 2020 Berg-Drazin. This is an open-access article distributed under the terms of the Creative Commons Attribution License, which permits unrestricted use, distribution, and reproduction in any medium, provided the original author and source are credited. 
Nils Rosen von Rosenstien - 1768:

"When children do not suck well, our old women say, that they are tongue-tied, and pretend that the bridle ought to be snipped with a pair of scissors. I have never as yet seen any child's tongue tied... If the child, when it shrieks, does not carry its tongue up to the palate, or to the outside of the lips, and the point of the tongue is not round but cloven as it were, we then know that its tongue is tied, but in other cases we may conclude that it is not; should an operation be judged necessary for it, it ought never to be done with the nails, but performed by some experienced man" [10].

William Moss -1794:

"A child's being tongue-tied will impede and hinder his sucking freely. When that happens, he may be observed to lose his hold very often, and, when he draws the breast he frequently makes a clicking noise. Upon this occasion the mouth must be examined and the tongue set at liberty by cutting a ligament or string which will be found to confine the tongue down to the lower part of the mouth" [11].

Pare A (1840-1841), Mukai, S. credits Pare with the concept of ankyloglossia and modification of the frenectomy devised by Egine, Paul $(625-690)$ to detach the tip of the tongue to the genioglossus muscle" [12].

\section{Chase AW-1874:}

"When babes are tongue-tied, they draw air into the stomach in nursing, and if a babe is constantly bothered with colic, the tongue should be examined to see if it needs cutting" [13].

"TONGUE-Tied-The tongue is fixed to the lower part of the mouth by a membranous cord, which presents too grat a degree of motion. Sometimes the cord ties down the tongue of infants so much that they cannot suck. This is supposed by the common people to be the case much oftener than it really happens; but so long as the patent sucks there is no occasion for any operation. But it happens sometimes that the tongue is not perceived to be tied till the child begins to articulate, and is prevented from forming certain letter for which free motion of the tongue is reguisite. At whatever time the operation may be necessary it is easily done by a pair of scissors; but the surgeon must be careful not to would any of the neighboring large vessels" [14].

Ankyloglossia is not a new phenomenon, nor is it a "fad" it has been diagnosed and documented since the Old Testament. Through ongoing research and study, we continue to learn how it impacts different facets of life. Parents need accurate information on this topic as well as support so that they can choose the appropriate treatment for their child.

\section{Competing Interests}

The author declare that there is no competing interests regarding the publication of this article.

\section{References}

1. Mukai S (2017) Ankyloglossia with Deviation of the Epiglottis and Larynx (ADEL). Annals of Clinical Otolaryngolgy 2: 1021.

2. Old Testament Exodus.

3. King James New Testament.

4. Aristotle (384 -322 BC). On the Parts of Animals. Book II. Part 17 Translated by William Ogle
5. Celsus AC (1592) De re medica libri octo. LugduniBatavorum: Ex officinaPlantiniana, apud Franciscum Raphelengium. From Obladen M (2009) Much Ado about Nothing: Two Millenia of Controversy on TongueTie. Sources of Neonatal Medicine.

6. Galenus C (1968) De usupartium corporis (transl Tallmadge May M). Ithaca, Cornell Univer- sity Press. From Obladen M (2009) Much Ado about Nothing: Two Millenia of Controversy on Tongue-Tie. Sources of Neonatal Medicine.

7. Pechey J (1697) A general treatise of the Diseases of Infants and Children. London.

8. Eminent Physician (1729) The Nurse's Guide" Or, the Right Method of bringing up Young Children. London Pages.

9. Theobald J (1764) A Young Wife's Guide in the Management of her Children London.

10. Rosenstien NR (1768) The Diseases of Children and Their Remedies. Stockholm.

11. Moss W (1794) An essay on the management, nursing and diseases of children from the birth: and on the treatment of diseases of pregnant and lying-in women: With remarks on domestic practice of medicine. Egham, United Kingdom: Boult \& Longman.

12. A Paré (1970) De l'empeschement et retraction de la langve(the restriction and holding back of the tongue (thank you Jennifer Welch for assistance with the translation) In: Malgaigne JF, ed. Amboise Paré; Oevrescomplétes; Réimpression de l'édition de Paris (1840-1841). Genéve: Slatkine Reprinte.

13. Chase AW (1904) Cholera Infantum, or Summer Complaint of Infants. Ed: Goodenough J. The Favorite Medical receipt Book and Home Doctor. Detroit, Mich. F.B. Dickerson Co. ed: Goodenough J.

14. Chase AW (1874) Dr Chase's Recipes Information for Everybody: An Invaluable collection of about eight hundred practical recipes for merchants, grocers, saloon-keepers, physicians. Dr Chase's Steam Printing- House, R.A. Beal Proprietor Ann Arbor Mich. 